\title{
Notas críticas em Serlio
}

\section{Vânia Cristina Cerri}

omenta-se aqui um tratado retórico-poético proferido pelo arquiteto italiano Sebastiano Serlio, intitulado "Tratado sobre as cenas", pertencente à obra Da arquitetura e perspectiva (publicada a partir de 1537) e que trata dos gêneros de cena teatral no século XVI. Este estudo do objeto artístico (o próprio "Tratado") parte de uma hipótese mimética, que considera as preceptivas (fixadas na Grécia e em Roma) e os gêneros de discurso pensados a partir de uma memória de tradição, memória esta que não se relaciona com o empírico, pois não imita o empírico e sim o discurso. A preceptiva acerca das artes pictóricas e poéticas do século XVI é a tônica que possibilita compreender melhor esse tratado.

Seguindo estes pressupostos, o tratado rejeita qualquer visão anacrônica, operando com o decoro (adequação) ao gênero, por meio do elogio à arte e ao artífice. Nessa dignificação do artífice, Serlio define os elementos próprios aos gêneros de cenas - a tragédia, a comédia e a sátira tratando-os como imitações das açôes humanas.

$\mathrm{Na}$ noção de imitação, conforme lemos na Poética de Aristóteles, o que se imita são as ações humanas, as quais demonstram que "necessariamente, os homens são de elevada ou de baixa índole, sendo estes distintos pela virtude ou pelo vício."
Ao discorrer sobre as cenas trágicas, Serlio enumera seus elementos: acontecimentos amorosos e casos que ocorrem em "grandes edifícios reais e senhoris" com príncipes, senhores e duques. Nas cenas cômicas, trata-se da imitação de personagens privadas ou cidadãos comuns - advogados e mercadores, como exemplo - cenas estas que ocorrem em suas residências. Já as sátiras, que representam gente rústica, serão ornadas com árvores e elementos rústicos e agrestes.

Serlio principia o tratado com uma descrição da composição da obra acomodada e conveniente ao preceito do decoro (decorum), sendo para tanto ornada e agradável (a fim de cumprir com os ofícios do movere e delectare, partes da construção do discurso retórico). Pela imitação, os movimentos da alma são manifestados através dos do corpo, o que se obtém com variedade e copiosidade das coisas (função da elocutio, outra parte da retórica), resultando no elogio à arte.

O uso dos preceitos da elocução, variedade e copiosidade (lê-se na arte poética de Horácio), cumpre retoricamente a função de agradar, comover e ensinar. Estes preceitos estão presentes no "Tratado sobre as cenas", compondo um exórdio para a captatio da benevolência no ouvinte, conforme explicita Quintiliano nas Instituiçōes Oratórias.

Vânia Cristina Cerri é pesquisadora, mestre em História e Estética da Arte pela FFLCH-USP. 
Ainda no exórdio do "Tratado sobre as cenas", vemos o emprego de uma doutrina genérica do decoro necessário para o gênero epidítico (demonstrativo, que pode ser para elogiar ou vituperar) presente já no Ut pictura poesis de Horácio. A doutrina trata da categoria "distância”, utilizada nos termos 'de perto e longe'. Ou, segundo diz Horácio: "Como a pintura é a poesia: coisas há que de perto, mais te agradam e outras, se à distância estiveres."

Ao mesmo tempo em que move e agrada, o "Tratado" ensina a arte, dispondo os artifícios apropriados que operam na cena diante do espectador e ensinando o modo de fazê-los. Assim elogia tal arte e a recomenda ao leitor.

Para tanto Serlio utiliza uma série crescente de qualificações, que compõem um discurso ornado produzindo deleite ao leitor/espectador. Opera também com o História Natural de Plínio, comparando os ornatos das cenas artificiosamente ordenados (obras humanas) com as pedras preciosas (obras da natureza), destacando desse modo a importância dos materiais e procedimentos, tudo no encômio ao artífice.

Utilizando os lugares da arquitetura, Serlio trata da representação teatral, elogiando a arte que produz a "maravilha" (efeito de deixar o espectador estupefato). O discurso de Serlio, ao agradar, proporciona melhor visão ao espectador, e explicita a ênfase dada ao olhar. Enumerando os elementos do aparato da cena, agrada com os artifícios produzidos, ensinando o modo de fazê-los, e operando com o gênero médio (pertencente ao demonstrativo).

Ao discorrer sobre o decoro do gênero das cenas, Serlio reitera Vitrúvio (século I a.C.), sua principal fonte - que por sua vez encontra-se ancorado na poética aristotélica-horaciana e na retórica greco-latina.

Bebendo na fonte do Da arquitetura de Vitruvio, Serlio discorre acerca dos três gêneros de cenas, exemplificando e prescrevendo a construção de cada uma delas, utilizando as regras da perspectiva. Estabelece uma hierarquia de gêneros, recirculando Vitrúvio no que concerne à disposição (dispositio) - definida pelo autor romano como ordenação conveniente de partes.

$\mathrm{Na}$ hierarquia de gêneros Serlio elege a cena trágica como sendo "o gênero alto", que extrai todos os seus elementos da Antigüidade; enquanto a cena cômica compreende as construções de obras modernas (opera moderna), termo empregado no século XVI.

No Da arquitetura, Vitruvio define as espécies da disposição (da cena) como: a ichnographia, que é o traçado em planta; a orthographia, ou seja, a imagem da fachada em elevação pintada segundo uma razão (proporção); e a scaenographia, a pintura da frente e dos lados com o encurtamento de todas as linhas visuais para o centro do círculo (circini centrum).

Ao tratar das espécies de disposição conforme Vitrúvio, Serlio, no Da arquitetura e perspectiva, mantém os termos "icnografia" e "ortografia", empregando o termo "scenografia" com a mesma definição que Vitrúvio utiliza para a scaenographia, isto é, "a frente e os lados de um edifício, como também de qualquer superfície ou corpo" (livro II do Da arquitetura e perspectiva de Serlio). Estabelece uma analogia entre a perspectiva (regras construtivas) e a "scenografia", definida acima. Por vezes modifica o termo scaenographia substituindo-o por "sciografia" - o qual define como a redução por sombras, com sombreamento que ressalta os relevos.

Os termos "sciografia" e "scenografia" aparecem em outros lugares no decorrer do $D a$ arquitetura e perspectiva. Entretanto, nunca são mencionados no "Tratado sobre as cenas". Há menção apenas do termo "scene", traduzido como "cenas", o que pressupóe que a cenografia no sentido moderno do termo não constava enquanto prescrição, embora as hipóteses desse estudo venham ressaltar toda a contribuição de Serlio para a prática cênica.

As contribuiçôes para a cenografia nesse século são crescentes, com arquitetos e tratadistas como Baldassare Peruzzi, Vincenzo Scamozzi, Andrea Palladio e Girolamo Genga - este último citado por Serlio. A partir dos lugares próprios da arquitetura e da pintura, que 
denominam de "arte antiga" (à maneira dos romanos), tratam esses arquitetos da arte de construir perspectivamente a cena, e de todo engenho teatral.

Evidencia-se portanto, nesse quadro sucintamente esboçado, a singularidade da obra e do seu artífice (Serlio). "Tratado sobre as cenas" apresenta-se enquanto uma prescrição e enumeração dos artifícios, aparatos e ornatos adequados a cada cena. Sabe-se que várias são as descriçōes de aparatos feitos para cenas no século XVI. Um exemplo é a descrição feita por Giorgio Vasari em 1568 do aparato preparado em Firenze para o príncipe Don Francesco de Medici - descrição que segue o decoro de uma cena variada e copiosa, própria do século XVI. Ao tratar do mesmo tema, Serlio se diferencia de Vasari, pois ao enumerar os aparatos da cena, exemplifica e ensina o modo de fazê-los. Justifica-se também sua diferenciação para com Vitrúvio, pois por meio da enumeração e dos exemplos ensina ainda o modo de fazê-los, preceituando, por conseqüência, a própria prática cênica do século XVI.

Afirma-se que para compreender esse tratado enquanto obra do século XVI é preciso levar em conta a importância dos gêneros do discurso e sua conveniência (adequação) com a arte. $\mathrm{O}$ conceito de estilo, utilizado como prin- cípio para compreender este tratado, impede a interpretação da obra. O que para muitos estudiosos é tomado como singularidade - as preceptivas - é na verdade uma constante nas artes até o século XVIII. Nesse contexto, a obra não se explica pela via empírica, e sim pelas doutrinas da retórica clássica. E, no século XVI, a parte mais utilizada dessa retórica é aquela que recomenda a tópica da emulação.

$\mathrm{O}$ anacronismo utilizado em alguns estudos desapropria e não reconhece os artífices com designação própria. Elabora-se, a partir do século XIX, uma história da Arte, da Filosofia, da Ciência e da Literatura - nas quais estas aparecem enquanto uma sucessão descontínua (psicologizante e positivista), chamada estilo, antes ausente nas artes. $\mathrm{O}$ estilo enquanto tal se desprende das preceptivas retórico-poéticas, passando a periodizar "positivamente" histórias "progressistas" como o Classicismo, o Barroco, o Maneirismo e outras.

As obras devem ser analisadas sem apelo a psicologismos, uma vez que não expressam a experiência pessoal do artista, mas sim regras e preceitos codificados retoricamente. Há que se considerar portanto os preceitos retórico-poéticos elaborados segundo esquemas de figuração e gêneros do discurso, assim como a materialidade e suporte do objeto. 